\title{
Good Governance of The European Prosecution Services in The Anti-Corruption Context ${ }^{1}$
}

Elnur Musayev²

\section{ABSTRACT}

Good Governance standards have been filled with some value in various international instruments. Originally viewed as a process of decision-making or means to achieve certain political goals, the Good Governance has turned into set of mandatory reform measures at the public and corporate level. The opinion on the role and impact of these standards in the context of the fight against corruption differ significantly according to opposing academic views. The standards in this area have been applied effectively in the course of the EU Integration and Council of Europe's evaluations. In practical terms, these standards have been 'translated' into specific measures, supported by the strong conviction that proper administration of these standards would produce positive effect in the fight against corruption. The internationally credited indicators show that countries with the adequate Good Governance structure in place are champions of controlling corruption. The underperformers in Good Governance also perform poorly in curbing corruption. However, qualitative analysis shows that the countries may put in place costly transparency and accountability mechanism and still fail in the fight against corruption. The research reveals no strong link between the application of

\footnotetext{
1Received in: 19/05/2017. Approved in: 02/06/2017.

2 Bachelor of Science in International Relations and Social Sciences from Khazar University, Azerbaijan, LLB from Baku State University, Azerbaijan, Master of Arts in Law from the University of Sheffield, UK, and Master of Anti-Corruption Studies from the International Anti-Corruption Academy. E-MAIL: elnur.musayev@prosecutor.gov.az
} 
the Good Governance standards and reaching a successful result in the fight against corruption. Perhaps only proper environment and support by additional necessary measures could produce the required effect. Otherwise, this Good Governance reforms in the country, especially prosecution service, may turn into formalistic exercise yielding extreme forms of corruption.

Keywords: Good Governance. Accountability. Transparency.

\section{INTRODUCTION}

Depending on the theoretical approach, the term Good Governance is used to refer to decision making process or means to achieve political goals with a very specific agenda. It is usually invoked in the context of the fight against corruption or development of a country. The prosecution service has crucial role in the fight against corruption. No matter how significant and cost-effective preventive measures are, the prosecution of corrupted officials comes as a powerful tool, perhaps the most effective in the arsenal. And the standards of Good Governance apply to the prosecution service in the first place: accountability to the public, independence, immunity from interference, especially in decision making, prevention of the conflict of interests, high standards of ethical behavior, etc. These standards are promoted in the European prosecution services through several platforms, including EU accession and Council of Europe evaluations.

The level of adherence of the prosecution services in Europe to the transparency, accountability and independence and other Governance standards differs considerably. So does the level of perception and real situation with the fight against corruption in these states. Therefore, there is no specific answer to the question [of this research] about the degree of correlation between the enforcement of these standards in the prosecution service and the outcome of effective fight against 
corruption. In simple terms, hardly anyone would dispute about strong and mutually defining correlation between the level of independence, transparency and accountability in Aklagarmyndigheten ${ }^{3}$ and success in the fight against corruption in Sweden, or Valtakunnansyyttäjänvirasto ${ }^{4}$ and success in the fight against corruption in Finland. One may link adherence of these standards to the high position in the global ranking of perception of corruption in Sweden and Finland 5 . In fact, these institutions could be considered as beacons for 'anti-corruption' sanitation of public institutions and best-practice examples for their counterparts around the world. However, one would be less confident in making a similar assertion with regard to Прокуратурата на Република България 6 (Prokuratura na Republika Blgaria) or Direcția Națională Anticorupție ${ }^{7}$ and the situation with corruption in Bulgaria and Romania, countries whose position in the corruption perception index is far less impressive ${ }^{8}$.

Perhaps even the following arguments would not affect the above conclusions:

a) Swedish-Finnish firm TeliaSonera, of which 37 per cent is actually owned by the Swedish state, allegedly paid millions of dollars in bribes to secure business in Uzbekistan (UUTISET, 2016). For a long period of time, the prosecution authorities of both countries did not or perhaps could not, detect and investigate these illegal practices.

b) The EU Commission, in its Strategy Paper on progress in the enlargement process adopted on 6 October 2004, recognized that both Bulgaria and Romania fulfilled the political criteria for accession. These criteria encompassed inter alia the stability of institutions gua-

3 The Swedish Prosecution Authority.

4 The Finnish Prosecution Authority.

5 Finland and Sweden ranked $2^{\text {nd }}$ and $3^{\text {rd }}$ respectively in the TI's CPI among 167 countries and territories in 2015 (TI CPI, 2015); $3^{\text {rd }}$ and $4^{\text {th }}$ respectively among 174 countries and territories in 2014 (TI CPI, 2014); and both of them $3^{\text {rd }}$ among 175 countries and territories in 2013 (TI CPI, 2013).

6 The Bulgarian Prosecution Authority.

7 The Romanian Anti-Corruption Agency.

8 Bulgaria and Romania ranked $69^{\text {th }}$ and $58^{\text {th }}$ respectively in the TI's CPI among 167 countries and territories in 2015 (TI CPI, 2015); both of them 69 among 174 countries and territories in 2014 (TI CPI, 2014); and $77^{\text {th }}$ and $69^{\text {th }}$ respectively among 175 countries and territories in 2013 (TI CPI, 2013). 
ranteeing democracy, the rule of law, thereby covering various powers of the prosecution services in these countries. (Eur-Lex Europa, 2005)

These examples show that the correlation between the Good Governance standards and control of corruption is far more difficult to determine than it may appear at first sight. Certainly, the contradictory nature of these cases may not be simply reduced to the margin of error of the perception indices or formalistic nature of reform-making in these countries, given the rigor of the scrutiny in the EU accession process. In order to grasp the essence of this correlation, it would be necessary to understand many contributing factors, including the historical background, relevant theories underlying these standards and practice of fight against corruption in countries. Thus, the prosecution services in the region either evolved 'naturally', as in the Western Europe, or were built from the scratch recently in tune with the God Governance agenda in the course of the recent EU integration process, as in the Eastern Europe.

\section{RESEARCH METHODOLOGY}

In order to test this correlation, the indicators and figures of international organizations are taken as the basis for a quantitative research, propped up by the qualitative research on case studies. The complexity lies in absence of indicators specifically pertaining to the prosecution service. Moreover these indicators are based on perception rather than performance. Also the statistical data on the performance of the prosecution services per se do not explain its efficiency in an objective manner. The figures and data on fight against corruption frequently prove to be controversial and less convincing the international community. According the statistics produced by the Anti-Corruption Directorate of the Republic of Azerbaijan', it in-

9 It is a specialized national anti-corruption investigation agency within the meaning of Article 36 of the UNCAC. 
vestigated 1,076 criminal cases and prosecuted 1,860 defendants for corruption offences in 2006-2014. During the same period, the ACD has taken provisional measures to recover damages of 198,070,786.00 Manats, at the time slightly less than the equivalent amount in Euros. However, the statistics produced hereafter would list the name of the country among the poor performers in many areas, including controlling of corruption. Also, the low level of investigations or prosecutions could be due to an array of factors totally irrelevant to its performance capacity, such as weak detection ability of auditing authorities and sectoral supervisors, absence of whistleblower protection or reporting mechanisms, etc. In the course of the research, the country profiles are attributed to clusters, which are subsequently tested against various economic and governance indicators. This exercise is performed in order to discern links and establish patterns for the ensuing conclusions. In summary, the indicators and other data deduced from the thematic and country reports, case studies are analyzed through generalization, comparison, multiple source validation, collation and pattern identification.

\subsection{Governance Standards and Fight against Corruption}

Transparency, accountability and independence are seen as a part of the wider concept of the 'Good Governance'. (UN OHCHR, 2016) (UNESCAP) There is no comprehensive definition of this concept in any regulatory instrument, whether at the national or international level. Nevertheless it has been confidently accepted and deeply enrooted in minds of the professionals and evoked strong confidence in the ranks of the population. These standards are not set forth in the internationally binding treaties, but only in the series of the international instruments of soft nature and study reports ${ }^{10}$. They have

10 Such as Recommendation Rec(2000) 19 of the Committee of Minister of the Council of Europe on the Role of Public Prosecution in the Criminal Justice System, The 1990 United Nations Guidelines on the Role of Prosecutors, Report on European Standards as Regards the Independence of the Judicial 
been issued at international and regional levels, as a result of broad analysis, and were not accompanied by enforcement mechanisms. Although their enforcement was not purported to be of mandatory nature, the principles reflected therein were pushed through country evaluation mechanisms, e.g. in the EU accession process reports and Council of Europe's GRECO evaluations ${ }^{11}$.

The fight against corruption, in its turn, is seen as an indispensable part of every proper governance system. The government may launch fight against corruption as the initial step of reforms on par with enforcement good corporate or public governance, promotion of transparency and accountability. According to this position, the proper regulation of the public administration, establishment of the free and liberal market eventually leads to the attraction of foreign investments, growth of economy and sustainable development of a country. (Daniel Kaufmann, Kauffman, 2009) (Andrews, 2008) (Christiane Arndt, 2006) This view could be characterized as the good governance or market-enhancing governance approach. Corruption is seen as the misfortunate granting of extensive powers to greedy officials. (Rose-Ackerman, 1997) Naturally, the response to the problem of corruption is about attacking the discretion, improving the well-being, securing prosecutions and encouraging transparent decision-making.

Alternatively, the government may push the agenda of profound economic or political reforms, turn a blind eye on concomitant corruption practices, and aim at securing consistent economic development and boosting of the market. Thereupon, it may gradually introduce the transparency and accountability standards, which, in its turn, will stimulate fight against corruption. According to this scenario, curbing corruption comes second as a means of securing continuous development of a country. (Khan M. ,2007) This is a

System: Part II - The Prosecution Service, etc.

11 GRECO evaluation mechanism can invoke a set of measures, including compliance procedures, which include additional reporting, addressing the authorities at high level. 
'growth-enhancing' approach. The followers of this approach view the opposing Good-Governance approach only as a 'one size fit all' objectives list, which distracts the necessary resources from real priorities. The 'growth-enhancing' approach suggests that transparency and accountability, as well as prioritization of anticorruption measures shall give in to more compelling country-specific analysis. The government shall take into consideration the peculiarities of corruption in each country, push feasible institutional changes and develop strategies accelerating economic and social transformations in the first place. (Khan M. , 2006)

\subsection{Good Governance in the Prosecution Service}

A great variety of prosecution services present in Europe come from a diversity of the legal traditions and culture of people populating the region. The convergence of the prosecution service took place in the course of the EU integration. This process focused mainly on the independence of the judiciary, the EU reformers hit the 'overarching functions of the prosecution services affecting the independence and functionality of the entire justice system' of the countries at the time acceding the EU. Therefore it required robust transformation in these institutions with a view to securing their conformity with the transparency and accountability standards, as in the case of the Czech Republic and Poland. (Rijksuniversiteit Groningen, 2008) Meanwhile, the Netherlands moved in the direction of gradually allocating adjudicatory powers, which were formerly the exclusive domain of the judiciary, to the prosecution service, i.e. granting it the power to resolve a great proportion of cases outside the court. (Tak, 2005).

\subsection{Analysis of the indicators}

For the purpose of this research, 36 European countries were 
chosen, which have passed evaluation stage ${ }^{12}$ of the Fourth Evaluation Round on the Prevention of corruption in respect of members of parliament, judges and prosecutors ${ }^{13}$. In the evaluated countries, the prosecutors/prosecution service have been checked according to the criteria of the conflict of interest, prohibition or restriction of certain activities, declaration of assets, income, liabilities and interests, enforcement of the rules regarding conflicts of interest, awareness. Subsequently, the data were reviewed according to the World Governance Indicators of Voice and Accountability, Political Stability and Absence of Violence, Government Effectiveness, Regulatory Quality, Rule of Law and Control of Corruption. (WGI, 2016) Subsequently the clusters were matched with the economic indicators and indicators of the participation of civil society.

So, initially the countries were matched into three clusters by their respective positions in the tables: Top Level Countries (TL), Middle Level Countries (ML) and Base Level Countries (BL). Top Level countries are Belgium, Denmark, Estonia, Finland, Germany, Iceland, Ireland, Luxembourg, Netherlands, Norway, Portugal, Sweden, France, Malta and United Kingdom (lined in alphabetical order). Malta did not perform well on Government Efficiency, which put it into the $21^{\text {st }}$ Position among 36. Malta also gained the $16^{\text {th }}$ Position in the Corruption Control rating. Similarly, Belgium, Estonia, UK and France performed poorly in the Political Stability and Absence of Violence (PS) rating. As a result, Belgium comes $18^{\text {th }}$, Estonia comes $17^{\text {th }}$, UK comes $20^{\text {th }}$ and France is on the $25^{\text {th }}$ positions. Malta is in the border area, between TL and ML countries. Middle level countries are Bulgaria, Croatia, Cyprus, Greece, Hungary, Macedonia FYR, Montenegro, Poland, Romania, Slovak Republic, Slovenia, Spain and Turkey (lined in alphabetical order). Turkey has performed well enough for this cluster in crucial areas of Government Efficiency, Rule of Law and

12 According to the GRECO Rules, the respective Governments have authorized the publication of the Country Evaluation Reports.

13 By the date of $1^{\text {st }}$ November 2016. 
Control of Corruption. Macedonia is in the border region, with proper performance only in Regulation Quality and Control of Corruption. It is among worst performers on Voice and Accountability. Serbia has similar results, however it underperforms on Control of Corruption, and therefore it is given a lower hand in the choice between it and Macedonia and falls in the Base Level cluster. Base Level countries are Albania, Armenia, Azerbaijan, Bosnia And Herzegovina, Moldova and Serbia

Subsequently, the above data was compared against the World Justice Project's Rule of Law index (WJP, 2016) The presumption here was that the countries with better Governance Efficiency perform better in terms of Rule of Law, which is composed of three components crucial for this research. A credible answer was expected as to whether the system of administration of justice, encompassing the prosecution service, performs well in countering corruption. While the WGI produced data on 36 countries, this Indicator produced data only on 26 countries, leaving 10 countries of out the scope of this research:

Table 1 WJP Indicators 2014-2015

\begin{tabular}{|l|l|l|l|l|}
\hline 1 & Country & $\mathbf{2 0 1 4}$ & $\mathbf{2 0 1 5}$ & Cluster \\
\hline 2 & Austria & $\mathbf{0 . 8 2}$ & $\mathbf{0 . 8 2}$ & TL \\
\hline 3 & Belgium & & 0.77 & TL \\
\hline 4 & Denmark & $\mathbf{0 . 8 8}$ & $\mathbf{0 . 8 7}$ & TL \\
\hline 5 & Estonia & $\mathbf{0 . 7 6}$ & $\mathbf{0 . 7 7}$ & TL \\
\hline 6 & Finland & $\mathbf{0 . 8 4}$ & $\mathbf{0 . 8 5}$ & TL \\
\hline 7 & France & $\mathbf{0 . 7 4}$ & $\mathbf{0 . 7 4}$ & TL \\
\hline 8 & Germany & $\mathbf{0 . 8 0}$ & $\mathbf{0 . 8 1}$ & TL \\
\hline 9 & Netherlands & $\mathbf{0 . 8 3}$ & $\mathbf{0 . 8 3}$ & TL \\
\hline 10 & Norway & $\mathbf{0 . 8 8}$ & $\mathbf{0 . 8 7}$ & TL \\
\hline 11 & Poland & $\mathbf{0 . 6 7}$ & $\mathbf{0 . 7 1}$ & TL \\
\hline 12 & Portugal & $\mathbf{0 . 6 6}$ & $\mathbf{0 . 7 0}$ & TL \\
\hline
\end{tabular}




\begin{tabular}{|l|l|l|l|l|}
\hline 13 & Spain & $\mathbf{0 . 6 7}$ & $\mathbf{0 . 6 8}$ & TL \\
\hline 14 & Sweden & $\mathbf{0 . 8 5}$ & $\mathbf{0 . 8 5}$ & TL \\
\hline 15 & United Kingdom & $\mathbf{0 . 7 8}$ & $\mathbf{0 . 7 8}$ & TL \\
\hline
\end{tabular}

As seen from this segment of the table, 14 out of 15 TL countries, covered by this indicator come as the best performers. It clearly shows that the countries with the best governance capacities have greater potential of performing well in the field of Rule of Law.

\begin{tabular}{|l|l|l|l|l|}
\hline 16 & Slovenia & $\mathbf{0 . 6 5}$ & $\mathbf{0 . 6 6}$ & ML \\
\hline 17 & Romania & $\mathbf{0 . 5 9}$ & $\mathbf{0 . 6 2}$ & ML \\
\hline 18 & Croatia & $\mathbf{0 . 5 7}$ & $\mathbf{0 . 6 0}$ & ML \\
\hline 19 & Greece & $\mathbf{0 . 5 9}$ & $\mathbf{0 . 6 0}$ & ML \\
\hline 20 & Hungary & $\mathbf{0 . 6 1}$ & $\mathbf{0 . 5 8}$ & ML \\
\hline 21 & Bulgaria & $\mathbf{0 . 5 3}$ & $\mathbf{0 . 5 5}$ & ML \\
\hline 22 & Turkey & $\mathbf{0 . 5 0}$ & $\mathbf{0 . 4 6}$ & ML \\
\hline
\end{tabular}

\begin{tabular}{|c|c|c|c|c|}
\hline 23 & Bosnia and Herzegovina & $\mathbf{0 . 5 5}$ & $\mathbf{0 . 5 7}$ & BL \\
\hline 24 & Macedonia, FYR & $\mathbf{0 . 5 8}$ & $\mathbf{0 . 5 5}$ & BL \\
\hline 25 & Albania & $\mathbf{0 . 4 9}$ & $\mathbf{0 . 5 2}$ & BL \\
\hline 26 & Serbia & $\mathbf{0 . 5 1}$ & $\mathbf{0 . 5 0}$ & BL \\
\hline 27 & Moldova & $\mathbf{0 . 4 5}$ & $\mathbf{0 . 4 8}$ & BL \\
\hline
\end{tabular}

WJP RoL indicator confirms the attribution of countries to clusters according to the WGI-based division. The only inconsistency, which originates from this comparison, is about the results on Turkey (deteriorating dramatically in 2015). However this is not the purpose of this research to find the reasons for such changes. The possibility of a link between the governance capacity and ability of its justice administration system were thus established.

The propositions of the 'growth-enhancement' approach could be tested through comparison of the clusters developed on the basis 
of the Good Governance indicators with the economic situation in countries, such as Nominal Growth Domestic Production, GDP Growth and Remuneration. There are several questions that may arise out the result of comparison. Is it only the economically sound countries that can sustain the costs of expensive good governance measures, including transparent and account prosecution services? Do the economically sound countries actually comply with the Good Governance standards for their public institutions? While the first question could be answered through the qualitative research; it is less likely that the findings of the proceeding collation with economic indicators may answer the second question. The conclusions of this exercise would be used in the next stage of the case studies. (infra vide)

Nominal Growth Domestic Production indicator was used as the primary source. (CIA, 2016) The majority of TL countries, 13 countries, positioned themselves at the top of the list on the economic growth rate. That indicates the possible strong mutually defining relations between the economic condition of a state and its governing capacity. According to the Growth-Enhancement approach, this link does not necessarily suggest that the latter brought about the former. To this effect speaks the position of Portugal and Estonia, which perform rather well according to the anti-corruption and good governance indices, but lag behind a number of worse governance efficiency performers. Location of BL country Azerbaijan above 2 ML countries, Montenegro and Macedonia, increase the doubt about the connection even further.

The next criterion for comparison is the dynamic, positive or negative, of the GDP. The results of the research shows that the GDP rates of big countries with a strong economy and best Governance Efficiency and Rule of Law are not growing fast. The GDP of smaller TL countries continue to grow at high rates. However, the presence of poor Governance Efficiency and Rule of Law performers, such as Bosnia and Armenia among the top 14 countries casts a serious 
doubt on the link. Off course the GDP growth rate is by no means a decisive and exclusive economic performance indicator.

High level of wages could be instrumental in the fight against corruption, maintenance of standards of Good Governance and economic development. According to Tanzi, reduction of wages may undermine the efficiency of public officials, hence the development of the economy counting on an input from the people working in the public sector. (Tanzi, 1990) Alternatively, some suggest that wage strategy is not efficient even in a country with low level of corruption and it requires a costly mechanism of supervision. (Besley \& McLaren, 1993) The comparison of wages does not allow deducing any strong link. Some of the ML countries, such as Cyprus and Slovenia, are paying higher salaries than some TL countries, as Estonia, Portugal and Malta. While the former could not outperform the latter in better governing and countering corruption, including in the criminal justice system, it could hint at small effect of the higher wages. That Serbia pays a lesser average wage to its employees supports this position too. Conversely, Bosnia, being a BL country underperforms according to the WGI, however, performs better economically, with its GDP growth level high above many countries of the ML.

As a measure of increasing transparency in the prosecution service, the Standards of Transparency and Accountability, foresee wider involvement of civil society in the work of the prosecution service. A good example is the participation of the civil society representatives in the work of the prosecutorial councils, a body of self-regulation with wide range of powers. Participation of a public representative in the work of this body may serve to the enhancement of public input element of the prosecutorial accountability. Depending on the qualities and capacity of the civil society representatives, level of their organization, qualification, expertise and commitment, as well as the environment where they operate, they may indeed have a great positive impact on the prosecution service in terms of increasing its 
transparency and accountability. However, one may not deny that poorly organized, low qualified representative who lacks proper expertise and could potentially be open to corruption incentives will not provide benefit to the organization.

The developed clusters of countries have also been compared by the level of impact that their civil society may exert, depending on their capacities and surrounding environment, as per the civil society indicator. (CIVICUS, 2009) The result shows that civil society is weak in Base Level countries (Armenia and Azerbaijan). Civil society in ML countries have great commitment to their causes, such as Macedonia, Poland, Romania, Bulgaria, etc. But their organizational structure is weak. Civil society in some of the ML countries manages to amass and impose substantial impact, as in Macedonia and Cyprus. Civil society in advanced countries, such as Germany, is not capable of imposing impact. Therefore the question remains, how viable is it demanding wider participation of civil society in the work of the prosecution service and would it really be effective.

\section{CASE STUDIES}

Case Studies for this research covered Serbia, Romania, Austria and Germany.

Serbia. The Serbian Prosecution Service is independent by Law. According to the Center for Liberal-Democratic Studies the corruption is still a widespread and dangerous phenomenon in Serbia. (SELDI, 2014) USAID estimates, that government procurement in Serbia in 2002 amounted to $\$ 1.45$ Billion US or 11.3\% of Gross Domestic Product (GDP) of which 15-20\% found its way into private hands.. (UNDP, 2005) The Serbian Prosecution Service, along with other law enforcement institutions were blamed inefficiency. Specifically it was blamed for protracted investigation of the so-called "questionable privatizations" cases, with Justice Minister Snežana Malovi $\square$ making a statement 
blaming Organized Crime Prosecution service. (ACC Serbia, 2011b) The country does not perform well economically, which manifests itself also in low wages to its employees. GRECO evaluation has recognized the existence of serious problems in the fight against corruption. However its recommendation envisioned some organizational measures, such as changing the composition of the State Prosecutorial Council. Furthermore, the Serbian Prosecution Service has adopted a Code of Ethics for the prosecutors, in order to satisfy the requirements of transparency and accountability as a formality, failed to train its employees and underperformed in other areas. (GRECO, 2015) The international organizations reviewing Serbia's arrangements in the field of public administration, including Prosecution Service, do not seem to connect to the real cause of the problem and limited themselves to issuing recommendations of standard and general nature. Obviously, Serbia may pose as an example of failure of the Good Governance standards for the Prosecution Service. It is also indicative of the lack of meaning and effect of Good Governance measures applied in a formalistic manner.

Bulgaria. The prosecution service of Bulgaria enjoys functional independence according to law. It introduced and maintains necessary tools of transparency and accountability, such as Prosecutorial Council. i.e. Chamber of the Supreme Judicial Council, in charge of the prosecutors' affairs; relevant career rules; necessary integrity checks; periodic assessment and review of performance; proper rules of case distribution and management; rules and procedures for the prevention of conflict of interest; and asset declaration. (PRB, 2016) Nevertheless, from time to time the Bulgarian prosecution service is shaken by the scandals of high-profile corruption cases mismanagement or instances of flagrant corruption in its own ranks. In 2009, Bourgas Regional Prosecutor's Office, Angel ANGELOV had to resign and later was subject to investigation for the negotiation, over the phone, over securing high-ranking position through the Supreme Judicial Council 
in exchange for a bribe. (Novinite, 2009) Council of Europe's GRECO heeded these problems and issued recommendations on full assertion of the legitimacy and credibility of the prosecutorial council (chamber) enhancement of its role as guarantor of the independence and autonomy of prosecutors; strengthening the integrity checks carried out in respect of candidates to the post of prosecutor; periodic reviews and attestation; more rigorous enforcement of the Code of Ethical Behavior; random case allocation; enhanced training; increase in the authorities of initiating disciplinary proceedings against prosecutors; and regular checks of private interests. However, reforms in these lines do not seem to add value to the existing system of governance and anticorruption. Elaboration of certain aspect of the reform that already failed does not appear as a step forward in tackling corruption. With low average wage, small GDP and weak pace of economic development, it is one of the poorest performers positioned at the bottom of the Middle level countries. Clearly, Good Governance Standards as they are seen and applied right now do not connect to the essence of the problem and certainly are not solution to the problems of the prosecution in particular and the country in general.

Austria and Germany. The prosecutors in these countries may receive instructions internally and externally, at the local and federal levels. Thus the Federal Prosecutor General at the Federal Court of Justice is subject to supervision by the Federal Ministry of Justice. The Federal Minister of Justice is entitled to issue general and specific instructions directly to the Federal Prosecutor General. In Austria, there is an additional mechanism, according to which the minister may consult a body of prosecutorial experts; however, it is not mandatory in nature. More importantly, the minister of justice in Austria has to report such instructions to the Parliament. According to the Recommendation Rec(2000) 19 of the Committee of Ministers of the Council of Europe, prosecutors shall be and be seen to be impartial and free of any improper influence, particularly of a political nature. 
The instructions by the Government in a specific case must carry with them adequate guarantees of transparency and equity. An example of such safeguard could be a duty of the Government to seek prior written advice from the competent public prosecutor, to duly explain its written instructions, to see to it that, before the trial, the advice and the instructions become part of the file; and that public prosecutors remain free to submit to court any legal arguments of their choice even if they are under a duty to reflect in writing the instructions received. Furthermore, instructions not to prosecute are to remain exceptional and subject to an appropriate specific control, in order in particular to guarantee transparency. GRECO has recommended Germany to consider introducing an amendment abolishing the right of the minister to instruct and remained satisfied that Austria has such system in place. (GRECO, 2015) With regard to the appointment, promotion and other career decisions related to prosecutors, until certain level the decisions are made by the Minister of Justice, and for the rest (top) prosecutors the decisions are made at the Government level. At the regional level, the corresponding power is exercised by the local minister and local government. A minister may transfer this power to the competent Prosecutor General. Furthermore, in the recruitment process, the minister evaluates candidate's suitability and integrity for the prosecutorial position on the basis of the personal impression. GRECO stopped short of recommending introduction of and independent mechanism for career decisions on the prosecutors, such as establishment of the prosecutorial council or curtailing the discretion of the executive in this regard. In view of the above circumstances, Austria and Germany are clearly not tuned with the Good Governance standards of the Council of Europe on matters of appointment and external influence prevention. No direct intention or initiative has been declared so far by these respective institutions on the plans to introduce the appropriate changes. Nevertheless, the system of the prosecution in both countries has sufficient sa- 
feguards and tools preventing corruption. Clearly, the example of these countries signifies the indispensability of the relevant rules in the mentioned areas, subject to the overall proper operation and resilience of the system.

\section{CONCLUSION}

The Good Governance standards have significant effect on the capacity of the prosecution service to fight against corruption. The power of this effect differs in each country of the continent. Nevertheless it is not exclusive and the most decisive factor. A myriad of other factors could affect the capacity of the prosecution service to fight against corruption, including economic and political stability, education and culture in the country. These standards have been pronounced from high podia and reflected in the international instruments. They have been elaborated in great details through a series of soft law instruments and recommendations. Good Governance standards were given effect within the framework of the evaluations by international organizations and in the course of the accession to the European Union and evaluations. These standards are not applied in all countries in a similar way, with advanced countries of the continent missing a number of them in the institutional arrangement of their prosecution services. However, these advanced countries surmount the rest of the countries, which apply the full set of standard measures. This may lead to the conclusion that the application of these standards is not universally palliative, and may potentially produce adverse effects. The reason to that unfortunate result could be entrenched in different level of democratization and rule of law, peculiar culture, and governance capacity of the countries, as well as formalistic manner of the reforms. Similar measures, such as establishment of the prosecutorial councils, resulted in true democratization of the process and produced transparency in one set 
of countries and failed to do so in others. Similarly, the participation of the civil society in the work of the prosecution services is not a guarantee of success. Similarly, good wages play minor role in the fight corruption effectively, against the conventional view.

While the governments are the prime targets for blaming in the case of the failure of the application of such standards, there could be objective reasons for such unfortunate occurrences. The most obvious one is the high cost of building and running fair and independent prosecution service. Not every country could bear this cost. For countries with poor economic capacity, small rates of economic growth this task may become unrealistic. Countries like Estonia managed to develop alternative effective strategies to reach the similar successful results using resources that cost cheaper. The paradox of the situation lays in the fact that the countries with good economy do not need implementation of full set of Good Governance reforms. However, the argument of high cost of the Good Governance standards is not necessarily a good one. The conditions of operation of the prosecution services in the developed countries are said to contain sufficient alternative and cost-effective safeguards, which have powerful corruption prevention effect and can effectively replace the costly institutions and safeguards of the Good Governance reforms. This argument is based on the low perception of corruption in these countries. Moreover, the countries with advance level in political stability, regulative quality, freedom of expression, government efficiency have a set framework for effective upholding of the rule of law and controlling corruption on a country level. On the other hand, the countries with poor performance on the mentioned criteria are almost doomed to struggle with curbing corruption and upholding the rule of law.

Corruption in the prosecution services of the advanced countries appears to be low. However, it could be the subjective position dominant in these societies, which prevent open discussion on the 
necessity of conducting reforms similar to those pursued in less developed countries. Famous cases, like Tellia Soneria corruption scandal relevant to Finland and Sweden may be a good reason for such a discussion, review and probably reforms. Nevertheless, international organizations, such as GRECO take soft position in the matter, issuing non-mandatory recommendations in respect of these countries. Example of the developed and well-off countries demonstrates strong link also between the Good Governance standards and fight against corruption, since these Standards are used as benchmarks. But when these standards are only applied as only a part of the agenda of reforms, especially in the prosecution services, there is no guarantee that they will definitely foster the fight against corruption and development of a country.

With all the controversies and inconsistencies, the Good Governance standards continue to remain irreplaceable and valuable etalons for the proper operation of the prosecution services. In order to be effective they need to connect to the real cause of the problem. If they do connect and are supported by additional social, economic, cultural and educational mechanisms, they can bring about change. To this end, they shall be tailored to the specific needs of a country, include many stages of application. If the counties are rushed through the implementation of reforms to meet the high level of these standards, they miss the momentum for producing effective solutions to their problems. Therefore, their application shall be genuinely accepted as the continuing process, and be means rather than goals. 


\section{BOA GOVERNANÇA DO MINISTÉRIO PÚBLICO EUROPEU NO CONTEXTO DO COMBATE À CORRUPÇÃO}

\section{RESUMO}

Os padrões de boa governança foram preenchidos com algum valor em vários instrumentos internacionais. Originalmente visto como um processo de tomada de decisão ou meios para alcançar certos objetivos políticos, a boa governança se transformou em um conjunto de medidas de reforma obrigatórias ao nível público e corporativo. A opinião sobre o papel e o impacto desses padrões no contexto da luta contra a corrupção diferem significativamente de acordo com os pontos de vista acadêmicos opostos. Os padrões nesta área foram aplicados efetivamente no decurso das avaliações da União Européia e do Conselho da Europa. Em termos práticos, esses padrões foram "traduzidos" em medidas específicas, apoiados pela forte convicção de que a boa administração desses padrões produziria efeitos positivos na luta contra a corrupção. Os indicadores creditados internacionalmente mostram que os países com a estrutura adequada de boa governança são os campeões do controle da corrupção. Os países abaixo da média em boa governança também apresentam mal desempenho na redução da corrupção. No entanto, a análise qualitativa mostra que os países podem implementar mecanismos de transparência e responsabilização dispendiosos e ainda falham na luta contra a corrupção. A pesquisa não revela uma forte ligação entre a aplicação dos padrões de boa governança e o sucesso de uma luta contra a corrupção. Talvez apenas um ambiente adequado e suporte por medidas adicionais necessárias possam produzir o efeito necessário. Caso contrário, as reformas da boa governança no país, especialmente o Ministério Público, podem se transformar em um exercício formal que produz formas extremas de corrupção.

Palavras-chave: Boa Governança. Prestação de contas. Transparência. 


\section{REFERENCES}

ACC Serbia. Anti-Corruption Council of Serbia. Retrieved 04 20, 2015, from Serbia`s fight against corruption: politicians, taycoons and public enterprises: http://www.antikorupcija-savet.gov.rs/en-GB/press-clipping/cid1037-1458/ serbias-fight-against-corruption-politicians-taycoons-and-public-enterprises (2011, 03 05).

Andrews, M. The Good Governance Agenda: Beyond Indicators without Theory. Oxford Development Studies , 36 (4), 378, 381-383, 397-399, 2008.

Berglund, S. J.-K. The Handbook of Political Change in Eastern Europe. 3rd Editon ed. Cheltenham: Edward Elgar Publishing Limited. 2013.

Berglund, S. J.-K. (Ed.). The Handbook of Political Change in Eastern Europe (3rd Editon ed.). Cheltenham: Edward Elgar Publishing Limited, 2013.

Besley , T., \& McLaren, J. Taxes and Bribery: the role of wages. The Economic Journal (103), 119-141, 1993.

Christiane Arndt, C. O. Uses and Abuses of Governance Indicators. OECD Development Centre Studies, 2006.

CIA. The World Fact Book. Retrieved from Centra Intelligence Agency: https://www.cia.gov/library/publications/the-world-factbook/geos/uk.html, 2016.

CIVICUS. CIVICUS Civil Society Index (CSI). Retrieved from http://csi. civicus.org/index.php?option=com_content\&view=frontpage\&Itemid=1 , 2009.

Daniel Kaufmann, A. K. Governance Matters VIII: Aggregate and Individual Governance Indicators 1996-2008. Development Research Group Macroeconomics and Growth Team . 2009. 
Daniel Kaufmann, A. K. The Worldwide Governance Indicators: Methodology and Analytical Issues. (Policy Research Working Paper 5430). New York, NY, US: The World Bank - Development Research Group : Macroeconomics and Growth Team. $(09,2010)$.

EPRS. The Cost of Non- Europe in the Area of Organized Crime and Corruption. European Parliament. Brussels: EPRS I European Parliamentary Research Service. 2016.

EU Parliament. Democracy and Respect for Human Rights in the Elargment Process of the European Union. EU Parliament Briefings , p. 6. 1998, 0401 .

EUObserver. EU raises alarm on Bulgaria corruption. EUObserver . 2015, January 28.

Eur-Lex Europa. Commission Opinion of 22/02/2005 on the applications for accession to the European Union by the Republic of Bulgaria and Romania. Brussels. Retrieved from http://eur-lex. europa.eu/legal-content/EN/TXT/?uri=uriserv:OJ.L_.2005.157.01.0003.01. ENG\&toc=OJ:L:2005:157:TOC

European Commission. (2014). Report from the Commission to the Council and the European Parliament EU Anti-Corruption Report. Brussels: European Commission. 2005, 0621.

Flere, S., Hurrelmann , K., \& Klanjšek , R.. Lost in Democratic Transition? Political Challenges and Prospectives for Young People In South East Europe. Results of Representative Survey in 8 countries. Berlin, Maribor, Skopje: Friedrich Ebert Stiftung. 2015.

Frank Schimmelfennig, T. A. Enlargement and the Integration Capacity of the EU: Interim Scientific Results. MAXCAP Project "Maximizing the integration capacity of the European Union: , pp. 10-16. 2015, 0501. 
GRECO. Evaluating Reports. Forth Evaluation Round Corruption prevention in respect of members of parliament, judges and prosecutors. 2015-2016.

GRECO. Evaluating Reports. Forth Evaluation Round: Corruption prevention in respect of members of parliament, judges and prosecutors . 2015-2016.

GRECO. Prevention of Corruption in Respect of Memebers of Parliament, Judges and Prosecutors. Strassbourg: Council of Europe. 2015.

GRECO. Revised Questionnaire on Corruption Prevention in respect of Members of Parliament, Judges and Prosecutors . Retrieved 09 25, 2016, from Council of Europe's Group of States against Corruption: http://www. coe.int/t/dghl/monitoring/greco/evaluations/round4/Greco\%20(2012)\%20 22E\%20Questionnaire\%20Eval\%20IV\%20REVISED_EN.pdf. 2011, 0411.

Hillion, C. The Copenhagen Criteria and Their Progeny. In C. Hillion, EU Enlargement: A Legal Approach (pp. 1-22). Oxford: Oxford: Hart Publishing. 2005.

ICJ. Serbia's Judges and Prosecutors: The Long Road to Independent Self-Governance. Geneva: International Commission of Jurists. 2015.

Johnston, M. Civil Society and Corruption: Mobilizing for Reform. New York: University Press of America, 2005b.

Johnston, M. (Ed.). Civil Society and Corruption: Mobilizing for Reform. New York: University Press of America. 2005b.

Johnston, M. Syndromes of Corruption: Wealth, Power, and Democracy. Cambridge: Cambridge University Press, 2005.

Johnston, M. Syndromes of Corruption: Wealth, Power, and Democracy. Cambridge: Cambridge University Press. 2005. 
Khan, M. Governance and Anti-Corruption Reforms in Developing Countries: Policies, Evidence and Ways Forward. UNCTAD Journal(42), 12-14. 2006, November).

Khan, M. Governance and Anti-Corruption Reforms in Developing Countries: Policies, Evidence and Ways Forward. UNCTAD Journal (42), 12-14. 2006.

Khan, M. Governance, Economic Growth and Development. DESA. DESA ACC Serbia. (2011b, 23 06). Anti-Corruption Commission of Serbia. Retrieved 04 20, 2015, from Prosecution is "looking into questionable privatizations": http://www.antikorupcija-savet.gov.rs/en-GB/they-said-it/cid1040-1530/ prosecution-is-looking-into-questionable-privatizations 08, 2007.

Khan, M. Governance, Economic Growth and Development. DESA. DESA. 2007.

Novinite. Bulgaria Prosecutor Resigns over Magistrates Corruption Scandal. 2009.

OECD. OECD. Retrieved 08 12, 2016, from OECD ACN IAP 4th Round Evaluation Methodology: https://www.oecd.org/corruption/acn/Methodology-4th\%20Round-Istanbul-Action-Plan-ENG.pdf. 2016, 0422.

PRB. Prosecution Service of the Republic of Bulgaria. Retrieved 11 07, 2016, from http://www.prb.bg/en/prosecutors-office/history/.2016.

Rijksuniversiteit Groningen. Unity and Diversity of the Public Prosecution Services in Europe: A study of the Czech, Dutch, French and Polish Systems. Retrieved 10 20, 2016, from Research School of the Groningen Faculty of Law 'Incorporation and: http://www.rug.nl/research/portal/ files/2712234/14_thesis.pdf. 2008, 0612.

RJT. REPUBLI $\square$ KOG JAVNOG TUŽILAŠTVA REPUBLIKE SRBIJE - Public Prosecution Service of the Republic of Serbia. Retrieved 11 01, 2016, from 
http://www.rjt.gov.rs/sr/organizacija/o-rjt-u/istorijat. 2016.

Rose-Ackerman, S. The Political Economy of Corruption. In K. A. Elliott (Ed.), CORRUPTION AND THE GLOBAL ECONOMY (pp. 31-60). New York: Academic Press.

SELDI. (2014). Corruption Assessment Report in Serbia. Southeast Europe Leadership for Development and Integrity (SELDI). Belgrade: Center for Liberal-Democratic Studies CLDS. 1997.

Tak, P. Methods of Diversion used by the Prosecution Services in the Netherlands and other Western European Countries. UNOFEI (74). 2005.

Tanzi. Tax evasion: a model. Journal of Public Economics , 2 (4), 339-346. TI CPI. (2014). Transparency International's Corruption Perception Index Technical Methodology. Berlin, Germany. Retrieved from http://www.transparency.org/cpi2014/in_detail\#myAnchor1. 1990.

TI GCB. Transparency International. Retrieved 07 14, 2016, from Global Corruption Barometer: https://www.transparency.org/gcb2013/in_detail. 2016.

TI NIS. Transparency International's National Integrity System. Berlin, Germany. Retrieved from http://www.transparency.org/files/content/nis/ NIS_Background_Methodology_EN.pdf

TI. (2016). Transparency International . Retrieved 07 14, 2016, from Global Corruption Barometer: https://www.transparency.org/gcb2013/in_detail. 2011.

UN OHCHR. Good Governance and Human Rights. Retrieved from http:// www.ohchr.org/EN/Issues/Development/GoodGovernance/Pages/GoodGovernanceIndex.aspx UNDP. (2005).

Prosecuting Financial Crime: Guidelines for Judges and Prosecutors. Beograd: UNDP. Retrieved from http://www.undp.org/content/dam/serbia/Publications\%20and\%20reports/UNDP_SRB_Prosecuting_Financial_Crimes_-_Guidelines_for_Judges_and_Prosecutors.pdf. 2016. 
UNESCAP. What is Good Governance? Bangkok, Thailand. Retrieved from http://www.unescap.org/sites/default/files/good-governance.pdf. n.d. UUTISET. Finland: World's second-least corrupt nation? YLE UUTISET .

Venice Commission. (2010). Report on the European Standards as Regards the Independence of the Judiciary: Part II - The Prosecution Service. Council of Europe, European Commission for the Democracy through Law. Council of Europe. 2016, 0128.

WB Doing Business. Enforcing Contracts Methodology. Washington, US. Retrieved from http://www.doingbusiness.org/Methodology/Enforcing-Contracts. 2016.

WGI. Methodology for Evaluation. Retrieved from World Governance Indicators: http://info.worldbank.org/governance/wgi/index.aspx\#doc. 2016.

WGI. Methodology. Retrieved from Worldwide Governance Indicators: http:// info.worldbank.org/governance/wgi/index.aspx\#home. 2016.

WJP . World Justice Project . Retrieved 07 13, 2016, from Rule of Law Index Methodology: http://worldjusticeproject.org/sites/default/files/media/ rolindex2016_methodology.pdf. 2016.

WJP Rule of Law Index Methodology. World Justice Project. Retrieved 07 13, 2016, from Methodology: http://worldjusticeproject.org/sites/default/ files/media/rolindex2016_methodology.pdf

WJP. Historical Data. Retrieved from World Justice Project: http://worldjusticeproject.org/historical-data. 2016.

World Bank Group. (2016). Resilient Growth Among Rising Risks. South-East Europe: Regular Economic Report. 2016. 